\title{
STRATEGI BELAJAR MAHASISWA TERHADAP PENGEMBANGAN KETERAMPILAN BERBICARA
}

\author{
Citra Kusumaningsih ${ }^{1}$, Baharuddin $\mathrm{JH}^{2}$, Finny Anita ${ }^{3}$ \\ ${ }^{13}$ Program Studi Pendidikan Bahasa Inggris, Fakultas Bahasa dan Seni, \\ IKIP PGRI Pontianak, ${ }^{2}$ Program Pascasarjana Universitas Tanjungpura \\ Corresponding email: citra.kusumaningsih@gmail.com
}

Received: 10th of December 2019, Accepted: $4^{\text {th }}$ of March 2020, Published: $22^{\text {nd }}$ of December 2020

\begin{abstract}
Abstrak
Dalam situasi pandemi saat ini, pencapaian tujuan dari ketrampilan berbicara secara lancar dan akurat tidak cukup hanya ditentukan oleh strategi dosen untuk mengajar tetapi juga semangat mahasiswa untuk menggunakan strategi pembelajaran berbicara yang tepat. Penelitian ini bertujuan untuk mengetahui strategi pembelajaran apa yang digunakan oleh mahasiswa untuk mengembangkan keterampilan berbicara bahasa ingrris, apa strategi yang yang digunakan mahasiswa yang meemparoleh nilai speaking skill rendah dan tinggi kemudian strategi dominan yang digunakan peserta didik. Penelitian ini menggunakan studi deskriptif, dengan jumlah peserta 50 orang mahasiswa semester tiga, yang dipilih dari 5 kelas program studi pendidikan bahasa inggris di IKIP PGRI Pontianak. Alat pengumpul data, peserta diminta mengisi kuesioner dan melakukan tes berbicara. Hasil penelitian menunjukkan hampir semua strategi digunakan oleh mahasiswa untuk mengembangkan keterampilan berbicara, sedangkan perbedaan strategi yang digunakan oleh mahasiswa yang memperoleh nilai keterampilan berbicaranya rendah dan tinggi ditemukan pada frekuensi penggunaan strategi dan variasi strategi dalam pembelajaran keterampilan berbicara. Dari keenam strategi pembelajaran keterampilan berbicara, seperti yang ditunjukkan dalam penelitian ini, strategi yang dominan digunakan oleh peserta didik adalah strategi afektif.
\end{abstract}

Kata kunci: strategi pembelajaran bahasa, keterampilan berbicara, pembelajaran efl

\begin{abstract}
In the current pandemic situation, reaching the goals of learners' speaking skill fluently and accurately are not enough only determined by the lecturers' strategy but also learners' enthusiasm to use appropriate speaking learning strategy. The presents study aimed to identify what speaking learning strategy used by the learners, different strategies used by learners' who are having low and high achievement, and then the dominant strategy employed by the learners. The study applied descriptive study, then the participants were 50 third semester students, chosen from 5 classes of English education study program of IKIP PGRI Pontianak. The tools of collecting data, the participants were asked to fill a questionnaire and to do a speaking test. The findings revealed all strategies almost used by the learners to develop their speaking skill, meanwhile the different strategies used by the students who are having low and high achievement are found in frequency of use the strategies and varieties of strategy in learning speaking skill. From the six strategies of learning speaking skill, as indicated in this study, the dominant strategy which have been employed by the learners is afektif strategy.
\end{abstract}

Keywords: language learning strategies, speaking skills, efl learners 


\section{PENDAHULUAN}

Pembelajaran bahasa Inggris merupakan salah satu aktifitas yang terdampak oleh pandemic COVID-19, sehingga menghadirkan tuntutan kegiatan pembelajaran jarak jauh berbasis teknologi daring. Pembelajaran tersebut dilakukan sebagai upaya pemerintah mengurangi penyebaran virus COVID-19 dengan adanya pembatasan social dan kontak fisik. Kebijakan tersebut dikeluarkan oleh Menteri Pendidikan berupa Surat edaran Nomor 3 Tahun 2020 tentang Pencegahan Corona Virus Disease (COVID-19) pada satuan pendidikan yang menyatakan bahwa meliburkan sekolah dan perguruan tinggi. salah satu perguruan tinggi di Kalimantan Barat, IKIP PGRI Pontianak, Program Studi Pendidikan Bahasa Inggris menerapkan proses pembelajaran daring dengan memanfaatkan berbagai laman sistem khusus, diantaranya group whatsapp, aplikasi zoom meeting, dan youtube.

Pembelajaran jarak jauh menjadi alternatif lain yang diambil oleh pemerintah untuk keberlangsungan aktifitas pembelajaran tetap berjalan dengan baik. Aktifitas ini dilakukan dimana peserta didiknya terpisah dari pendidik dan pembelajarannya menggunakan berbagai sumber belajar melalui teknologi komunikasi, informasi, dan media lain (Undang-Undang Republik Indonesia no 20, pasal 1, tahun 2003).

Situasi ini secara mendadak dan cepat juga memberikan dampak bagi mahasiswa diantaranya unjuk performa dan interaksi selama proses pembelajaran mereka memungkinkan munculnya kendala pada saat proses pembelajaran berlangsung, disebabkan oleh sinyal jaringan internet yang kurang baik, sehingga berdampak pada.pencapaian pembelajaran bahasa inggris mereka, terlebih lagi pada keterampilan berbicara (speaking skills) bahasa inggris yang dianggap salah satu keterampilan yang paling tersulit untuk dikuasai oleh mahasiswa, seperti yang dikatakan oleh Mistar, Zuhairi, \&Umamah (2014) "Speaking is considered as the hardest skill in learning English and needs various strategies that should be integrated with speaking class" Kemampuan berbicara (speaking skills) bahasa inggris secara fasih dan tepat selalu menjadi tujuan utama mahasiswa mempelajari bahasa Inggris. Melalui keterampilan berbicara yang dilakukan dengan baik dan benar mahasiswa dapat memperoleh informasi maupun pengetahuan lebih banyak melalui interaksi yang dilakukan.

Ketercapaian mahasiswa pada keterampilan berbicara secara fasih dan akurat pada kenyataannya tidak semata-mata ditentukan oleh kualitas dosennya, namun juga keaktifan mahasiswanya menggunakan strategi belajar keterampilan berbicara bahasa inggris baik didalam kelas maupun diluar kelas, menurut Oxford (1990), Language Learning Strategy are a crucial aspect to consider because these strategies are essential for developing 
communicative competence that is needed in speaking. Situasi pembelajaran daring saat ini semakin memaksa setiap mahasiswa lebih aktif menggunakan strategi-strategi belajar yang berbeda atau lebih bervariasi, sehingga mengasah keterampilan berbicara mereka menjadi lebih baik dan menjadi pembicara aktif. Learning strategies are necessary to build students' motivation and help them to be independent in learning English (Jones, 1998).

Menentukan serta memvariasikan strategi belajar yang tepat, mampu meningkatkan secara signifikan proses belajar mahasiwa serta pemahaman belajar bahasa baru menjadi lebih cepat. O'Malley dan Chamot (1990) dari hasil penelitian mereka lakukan bahwa more effective (higher proficiency) students generally use a greater variety of strategies and use them in ways that help the student complete language tasks more successfully; conversely, less effective (low proficiency) students not only have fewer strategies but also frequently use strategies that are inappropriate to the task or that do not lead to successful task completion. Kemudian O'Malley dan Chamot (1989) dan Gu dan Johnson (1996) (didalam kutipan Gani, Fajrina, dan Hanifa, 2015) juga mengatakan bahwa successful learners made use of combinations of strategies. Ditambah lagi oleh Gharbavi and Mousavi (2012) yang menunjukkan bahwa the higher the level the learners are at, the greater the number of strategies they use. Maka dapat disimpulkan bahwa, strategi-strategi belajar merupakan cara terpenting untuk memperoleh informasi maupun pengetahuan baru dalam proses belajar yang bisa digunakan oleh mahasiswa sebagai pembelajar untuk membantu mereka mencapai pencapaian yang maksimal karena mampu memahami pengetahuan baru dengan lebih mudah, serta membantu mereka memecahkan permasalahan bahasa baru dengan lebih menyenangkan.

Pengelompokan strategi belajar dibagi menjadi 4 jenis: kognitif, meta-kognitif, efektif, dan sosial (O’Malley dan Chamot, 1990; Cohen, 1990; Oxford, 1990): (1) Strategi kognitif berhubungan dengan daya pikir pembelajar dalam mengolah bahan belajar mengajar. (2) Strategi meta-kognitif berhubungan dengan taktik atau cara pembelajar untuk menghadapi dan mengelola bahan belajar mengajar.(3) Strategi efektif berhubungan dengan sikap dan perasaan pembelajar dalam menghadapi proses belajar pembelajar. (4) Strategi sosial berhubungan dengan kerjasama pembelajar dengan sejawatnya dalam mencapai tujuan belajar.

Oxford (1990) menambahkan dengan membagi strategi belajar menjadi dua bagian besar: langsung dan tidak langsung :

1. Strategi langsung kemudian dirinci lebih lanjut menjadi tiga jenis; memori, kognitif, dan kompensasi: (1) Strategi Memori Strategi belajar memori digunakan oleh pembelajar dengan memanfaatkan pengetahuan dan pengalaman belajar sebelumnya. Strategi belajar ini banyak melibatkan ingatan dan proses pembelajaran yang menggunakan daya ingat. 
Misalnya, apabila pembelajar menghubungkan bunyi ujaran dengan hal-hal yang pernah diingatnya, maka ia sedang menggunakan strategi belajar memori. Termasuk dalam strategi belajar ini adalah mengulang pelajaran sebelumnya. (2) Strategi kognitif adalah segala perilaku pembelajar dalam proses belajar mengajar yang behubungan dengan penggunaan daya pikir pembelajar. Contoh diantaranya: mahasiswa memperbaiki kesalahan sendiri menggunakan gerakan isyarat, melatih mengucapkan kata, menulis dalam buku catatan, membaca dari papan tulis, dan menatap media ajar. (3) Strategi belajar kompensasi digunakan oleh pembelajar yang telah memiliki keterampilan- keterampilan yang cukup tinggi. Strategi belajar ini biasanya dimanfaatkan untuk menanggulangi beberapa keterbatasan dalam berbahasa. Pembelajar yang mengalami kesulitan dalam menerangkan sesuatu dalam bahasa yang dipelajari, misalnya dapat menggunakan definisi atau terjemahan dalam ujarnya untuk menjaga agar proses berbahasa tetap berjalan.

2. Strategi tidak langsung dibagi menjadi tiga: meta-kognitif, efektif, dan sosial. Masingmasing strategi memiliki jenisjenis kegiatan sendiri: (1) Strategi meta-kognitif adalah segala perilaku pembelajar yang berhubungan dengan teknik atau cara pembelajar untuk menghadapi dan mengelola bahan belajar mengajar. Dapat dikatakan bahwa semua ini harus datang dari dan dikerjakan oleh pembelajar, (2) Strategi afektif adalah segala perilaku pembelajar yang berhubungan dengan sikap dan perasaan pembelajar dalam menghadapi proses belajar. Strategi ini lebih lanjut dibagi menjadi dua: afektif positif dan afektif negatif. Strategi afektif positif adalah prilaku pembelajar yang menunjukkan bahwa pembelajar menerima dan menghargai proses belajar mengajar. Strategi afektif negatif adalah prilaku pembelajar yang menunjukkan bahwa pembelajar menolak dan tidak menghargai proses belajar mengajar. Perlu diperhatikan bahwa istilah “negatif” sebagaimana digunakan di sini tidak mengandung makna jelek atau buruk. Penolakan pembelajar tehadap proses belajar mengajar harus dipandang sebagai sikap yang "netral”,yang tidak berhubungan dengan nilai baik-buruk. Strategi afektif positif diwakili oleh empat prilaku: tertawa dengan menunjukkan kesenangan atau kepuasan, tersenyum menunjukkan kepuasan dan menunjukkan kesenangan karena hal-hal yang lucu menyenangkan. Strategi afektif negatif diwakili oleh beberapa perilaku: menunjukkan kebingungan, mengeluh, tidak memperhatikan dosen. (3) Strategi sosial adalah segala perilaku pembelajar yang berhubungan dengan kerja sama pembelajar dengan sejawatnya dalam mencapai tujuan belajar. Strategi ini diwujudkan dalam enam kegiatan: berbicara dengan teman sebangku mengenai pelajaran, membantu teman sesuai dengan kegiatan belajar mengajar, minta bantuan kepada teman, memberikan pujian kepada teman, dan mengganggu teman. 
Penggunaan strategi pembelajaran pada situasi yang berbeda saat ini serta informasiinformasi yang tertuang pada paragraph sebelumnya, maka peneliti tertarik melakukan penelitian pada mahasiswa program studi pendidikan bahasa inggris, IKIP PGRI Pontianak pada pengembangan aspek keterampilan berbicara (speaking skills), penelitian ini dilakukan untuk mengidentifikasi strategi pembelajaran speaking skills apa saja yang digunakan oleh mahasiswa pada masa pandemi saat ini, mengetahui strategi yang paling banyak digunakan oleh mahasiswa, dan strategi apa saja yang digunakan oleh mahasiswa yang mencapai nilai tinggi maupun yang rendah pada keterampialan berbicara bahasa inggris. Harapan dari penelitian ini, mahasiswa akan mengetahui berbagai macam strategi belajar speaking skills dan menerapkan bermacam variasi strategi pembelajaran tersebut sebagai upaya mengembangkan kompetensi diri

\section{METODE}

Desain penelitian adalah rencana penelitian peneliti yang meliputi metode yang akan digunakan, data apa yang akan dikumpulkan, dimana, bagaimana, dan dari siapa (Ary, 2006: 34). Sugiono (2012: 9) mengemukakan penelitian kualitatif sebagai metode penelitian yang berlandaskan pada filsafat postpositivisme, digunakan untuk meneliti pada kondisi objek alamiah, dimana peneliti adalah sebagai instrumen kunci, teknik pengumpulan data dengan triangulasi, analisis data bersifat induktif atau kualitatif, dan hasil penelitian kualitatif lebih menekankan makna daripada generalisasi. Penelitian deskriptif biasanya mempunyai dua tujuan, untuk mengetahui perkembangan fisik tertentu dan mendeskripsikan secara terperinci fenomena social tertentu. Kemudian Sugiono (2012:4-5), mengenai jenis-jenis metode penelitian dapat diklarifikasikan berdasar tujuan dan tingkat kealamiahan objek yang diteliti. Mengacu pada alat pengumpulan data, penelitian ini akan menggunakan metode campuran, desain kuantitatif dan kualitatif. Ini adalah desain penelitian yang mengumpulkan dan menganalisis data kuantitatif dan kualitatif dalam satu studi (Cresswel, 2010).

Subjek penelitian ini yakni, mahasiswa semester III program studi pendidikan bahasa Inggris yang memiliki kualifikasi memperoleh nilai keterampilan speaking tertinggi dan terendah, maka peneliti memutuskan untuk melakukan observasi awal. Hal itu dilakukan untuk mengetahui kemampuan dan karakteristik mahasiswa. Sebelumnya, peneliti terlebih dahulu berdiskusi dengan dosen-dosen pengampu mata kuliah. Hal itu dilakukan karena peneliti yakin bahwa mereka sangat mengenal kemampuan mahasiswanya. Beberapa kriteria dari subjek yang dipilih. Subjek penelitian adalah mereka yang: (1) Mahasiswa yang memperoleh nilai keterampilan speaking tertinggi dan terendah, yang ditunjukkan dengan skor. Skor diperoleh 
dari hasil tes speaking yang diberikan peneliti untuk mereka. (2) Direkomendasikan oleh dosen-dosen pengampu mata kuliah. (3) Direkomendasikan oleh teman-teman mereka yang sangat mengenal mereka.

Data kuantitatif diperoleh melalui angket dan nilai dari hasil angket tersebut, sedangkan data kualitatif dikumpulkan dari wawancara. Adapun analisis data yang digunakan dari hasil kuesioner dianalisa dengan menghitung skor rata-rata, kemudian skor tersebut dianalisis dengan mengurutkan dari skor tertinggi ke skor terendah. Sedangkan analisis kualitatif menggunakan reduksi data, data display, dan penarikan kesimpulan/verifikasi

\section{HASIL DAN PEMBAHASAN}

Adapun hasil penelitian dan pembahasan terlampir pada bagian ini. Data dikumpulkan melalui kuesioner dan wawancara. Hasil penelitian ini membahas tentang strategi belajar keterampilan berbicara bahasa Inggris yang digunakan oleh mahasiswa program studi pendidikan bahasa Inggris IKIP PGRI Pontianak. Bagian ini terdiri dari membahas tentang strategi pembelajaran bahasa digunakan oleh mahasiswa program studi pendidikan bahasa Inggris IKIP PGRI Pontianak, memaparkan tentang strategi yang paling dominan digunakan oleh mahasiswa tersebut, kemudian yang terakhir menyajikan tentang strategi yang digunakan oleh mahasiswa yang memiliki nilai tinggi maupun rendah pada kompetensi keterampilan berbicara

Peneliti memberikan kuesioner kepada mahasiswa program studi pendidikan bahasa Inggris semester tiga. Kuesioner terdiri dari pertanyaan tertutup. Selanjutnya kuisioner memberikan tiga puluh pernyataan. Kuesioner dibagi menjadi enam bagian, yakni bagian pertama adalah strategi belajar pada keterampilan berbicara dalam hal mengingat lebih efektif (memori strategi). Bagian kedua adalah pembelajaran bahasa mahasiswa strategi berbicara dalam menggunakan proses mental (kognitif strategi). Bagian ketiga adalah pembelajaran bahasa mahasiswa strategi berbicara dalam mengkompensasi pengetahuan yang hilang (strategi kompensasi). Bagian keempat adalah mahasiswa strategi berbicara pembelajaran bahasa dalam pengorganisasian dan mengevaluasi pembelajaran (strategi metakognitif). Bagian kelima adalah strategi berbicara dalam pembelajaran bahasa siswa dalam mengelola emosi (strategi afektif). Bagian keenam adalah mahasiswa belajar bahasa strategi berbicara dalam belajar dengan orang lain (strategi sosial).

Berdasarkan hasil yang ditemukan dari kuesioner, mahasiswa cenderung menggunakan strategi metacognitif dan strategi afektif diantara strategi lainnya. Strategistrategi ini mencakup aktivitas merencanakan, mengatur, mengelola, dan mengevaluasi. 
Temuan ini sejalan dengan penelitian sebelumnya lainnya (Ketabi \& Mohammadi, 2012; Simsek \& Balaban, 2008; Lee dan Heinz, 2016; Sheorey, 1999; Liu, 2004; Lee dan Heinz, 2016). Di sisi lain, kognitif strategi yang mencakup kegiatan berlatih dalam mengulang, berlatih, dan meniru bahasa adalah juga strategi yang paling banyak yang sering digunakan oleh yang mahasiswa. Sehubungan dengan sebelumnya belajar, itu juga menemukan yang biasa mahasiswa lebih disukai dalam menggunakan strategi kognitif (Khoshima, 2015; Bobanovic \& Ambrosi, 2006).

Pada dasarnya, pasti ada perbedaan strategi yang digunakan oleh mahasiswa karena ada banyak faktor yang mempengaruhi penggunaan strategi belajar mereka untuk pencapaian kompetensi, mereka tergolong pengguna strategi afektif. Berdasarkan data yang dianalisis, ditemukan beberapa perbedaan dalam kategori strategi dan ragam strategi yang digunakan oleh mahasiswa yang memperoleh nilai tinggi dan mahasiwa yang memperoleh nilai rendah. Berdasarkan pemerolehan data mahasiswa yang memproleh nilai tinggi pada keterampilan berbicara lebih sering menggunakan strategi belajar dan lebih bervariasi ketika menggunakan strategi untuk belajar, diantaranya dengan menghafal kosakata bahasa inggris, lebih sering berlatih kemampuan berbahasa inggris, dan sangat berhati-hati ketika berbicara agar tidak terjadi kesalahan, sementara, berbeda dengan mahasiswa yang memiliki nilai rendah pada keterampilan berbicaranya, yang kurang memanfaatkan strategi belajar untuk mengembangkan kemampuan keterampilan berbahasa inggris mereka.

Selanjutnya perbedaan yang ditemukan di antara strategi yang digunakan oleh mahasiswa yang nilai keterampilan berbicaranya tinggi dan rendah. Dari hasil, metakognitif, yang mana menjadi strategi yang paling banyak digunakan oleh mahasiswa yang memperoleh nilai tinggi dari keterampilan berbicarnya, sebaliknya hal ini berbeda dengan mahasiswa yang memiliki nilai rendah. Asumsinya bahwa mahasiswa yang berhasil memiliki nilai tinggi merencanakan tujuan yang jelas, kontrol, tinjauan, dan mengevaluasi pembelajaran mereka daripada mahasiswa yang nilainya rendah yang lebih focus dalam cara mereka berpikir, menghafal, merangkum, dan ulangi pembelajaran.

Meskipun beberapa strategi mungkin tampak lebih efektif daripada yang lain namun data dari hasil interview menunjukkan bahwa mahasiswa yang memiliki nilai tinggi lebih menggunakan strategi metakognitif dan mahasiswa yang memiliki nilai rendah mengacu pada penggunaan strategi kognitif, namun pada kenyataannya, tidak ada teori yang tepat menyatakan bahwa pasti strategi lebih unggul, karena banyak penelitian yang melaporkan hasil strategi yang berbeda-beda digunakan oleh mahasiswanya. Tetapi setiap strategi memiliki kelebihan dan kekurangannya masing-masing dalam mengelola pembelajaran. Salah 
satu faktor yang membuat mereka berbeda adalah pemikiran mental pembelajar diri, berdasarkan teori Oxford (1996) yang menekankan bahwa menilai pembelajar itu sendiri sebagai pribadi seutuhnya, tidak hanya berfokus pada aspek intelektual dari strategi, yang artinya jika mahasiswa bisa memilih yang mana strategi yang sesuai untuk mereka, maka itu akan sangat membantu mereka dalam belajar.

Ada karakteristik tertentu dari mahasiswa dapat ditemukan dari hasil penelitian mahasiswa yang memperoleh nilai tinggi menggunakan keenamnya dan mengkategorikan strategi dengan sangat sering daripada mahasiswa yang memperoleh nilai rendah, hal ini menunjukkan bahwa mahasiswa yang memperoleh nilai tinggi lebih sadar pentingnya strategi untuk diri mereka sendiri daripada mahasiswa yang memeperoleh nilai rendah, hal ini sejalan dengan pernyataan Chamot dan Kupper (1989) yang menemukan bahwa siswa yang berhasil menggunakan strategi belajar lebih sering, lebih banyak secara tepat, dengan variasi yang lebih besar, dan dengan cara yang membantu mereka menyelesaikan tugas berhasil daripada siswa yang tidak berhasil. Bahkan, Simsek \& Balaban, (2010) juga menyatakan yang digunakan siswa yang berhasil secara keseluruhan strategi secara signifikan lebih sering daripada siswa yang tidak berhasil. Nyikos (1987), juga mendefinisikan karakteristik sebagai siswa yang tidak berhasil yang sering terlibat perilaku non komunikatif seperti terjemahan dengan banyak penggunaan kamus, menghafal, melipat kertas ke dalam kolom untuk dibuat tes kosa kata mandiri, dan tidak kreatif bentuk pengulangan.

Hasil temuan peneliti menunjukkan bahwa mahasiswa yang memeperoleh nilai rendah cenderung menggunakan strategi kognitif yang difokuskan dengan mengulangi, melatih, dan meniru bahasa. Walupun mungkin belum cukup dibuktikan dalam temuan peneliti, tetap saja, hal itu tetap bisa dianggap sebagai faktor-faktor itu menjadi kelemahan ketidakb berhasilan mahasiswa dalam belajar. Temuan dari studi ini memberikan panduan untuk bahasa Inggris dosen dan mahasiswa, khususnya untuk proses belajar mengajar. Oxford (1898) menyatakan bahwa pembelajaran yang sesuai strategi membantu menjelaskan kinerja pelajar bahasa yang baik, hal ini penting untuk dikelola oleh dosen mengenai strategi yang tepat untuk mahasiswa.

Berdasarkan pemaparan diatas mengenai strategi belajar untuk mengembangkan keterampilan mahasiswa berbicara, diperoleh bahwa strategi yang dipilih oleh mahasiswa yang memiliki nilai tinggi yakni cenderung pada strategi metacognitive, strategi afektif, dan strategi kompensasi, berbeda dengan mahasiswa yang memiliki nilai rendah. Mahasiswa yang memiliki nilai rendah cenderung lebih dominan memilih strategi kognitive dan strategi afektif. 


\section{SIMPULAN}

Tujuan dari penelitian ini adalah untuk mengetahui strategi belajar untuk mengembangkan keterampilan berbicara yang digunakan oleh mahasiswa semester 3, program studi pendidikan bahasa inggris IKIP PGRI Pontianak. Peneliti memberikan kuesioner SILL (Study Inventory Language Learning) yang dibuat oleh Oxford dan melalui wawancara untuk menjawab pertanyaan kedua dari penelitian. Hasil penelitian menunjukkan bahwa hampir semua mahasiswa semester 3, program studi pendidikan bahasa inggris IKIP PGRI Pontianak menggunkan strategi belajar yang dirancang oleh Rebecca Oxford. Ini termasuk memori strategi, strategi kognitif, strategi kompensasi, strategi metakognitif, strategi afektif, social strategi. Namun yang paling dominan digunakan oleh mahasiswa adalah strategi metakognitif, kompensasi, dan kognitif.

Kemudian diantara semua strategi belajar, mahasiswa yang memperoleh nilai keterampilan berbicaranya tinggi biasanya lebih tinggi motivasinya untuk memperoleh keberhasilan akan keterampilan berbicara yang fasih dan akurat daripada mahaiswa yang memperoleh nilai rendah, terutama pada frekuensi penggunaan strategi, kategori strategi, dan variasi strategi yang digunakan.

\section{REFERENSI}

Ary, Donald, et.al. (2006). Introduction to Research in Education. Canada: Thomson.

Creswell, J. W. (2010). Research design: pendekatan kualitatif, kuantitatif, dan mixed. Yogjakarta: PT Pustaka Pelajar.

Chamot, A. U. \& Kupper, L. (1989). Learning Strategies in Foreign Language Instruction.Foreign Language Annual, 22. 13-24.

Jones, S. (1998). Learning Styles and Learning Strategies: Towards Learner Independence ELT for Modern Language Studies. Vol. xxx No. 2. Retrieved on August 25, 2015, from http://fmls.oxfordjournals.org/

KEMENDIKBUD. (2020, Maret Senin). Surat Edaran MENDIKBUD. Retrieved from Surat Edaran Nomor 3 Tahun 2020 Tentang Pencegahan COVID-19 pada Satuan Pendidikan: https://drive.google.com/file/d/15jxZumrgZy4eriSdx1SVAh2ZkKbCs3Ju/view

Khoshsima, H. \& Tiyar, F.R., (2015). Language Learner Strategies for Building EFL Learners' Autonomy. International Journal of English Language and Translation Studies 3(4), 60-73. Retrieved from http://www.eltsjournal.or

Mistar, J., Zuhairi, A., \& Umamah, A. (2014). Strategies of Learning Speaking Skill by Senior High School EFL Learners in Indonesia. ASIAN EFL JOURNAL, 65-74.

Nyikos, Martha. (2008). Gender and Good Language Learners. In Griffiths, Carol (Ed), Lessons from Good Language Learners. Cambridge: Cambridge University Press 
O’Malley, J.M. \& A.U. Chamot. (1990).Learning strategies in Second Language Acquisition. Cambridge: Cambridge University Press.

Oxford, R.L and Crookall, D. (1989). Research on Language Learning Strategies: Methods, Findings, and Instructional Issues. Modern Language Journal, 73(4). 404-419.

Oxford, R. L. (1990). Language Learning Strategies: what every teacher should know. New York: Newbury House Publishers.

Oxford, R.L. (1996). Language Learning Strategy around the World: Cross Cultural Perspective. Manoa, HI: Second Language Teaching and Curriculum Center, University of Hawai.

Sugiyono. (2012). Memahami Penelitian Kualitatif. Bandung: ALFABETA

Simsek, A. \& Balaban, J. (2010). Learning strategies of successful and unsuccessful university students. Contemporary Educational Technology, 1(1), 35-45. 